\title{
TUTOR'S ROLES AND PERFORMANCES IN MODERN HUMAN ANATOMY COURSE SUPPORTED BY VIRTUAL TECHNOLOGY
}

\author{
Dzintra Kazoka \\ Rīga Stradiņš University, Latvia \\ Mara Pilmane \\ Rīga Stradinš University, Latvia
}

\begin{abstract}
Dynamical development of technologies changes not only education system in medicine at Rīga Stradiňs University, but there are a lot of performances in roles of the tutors, their skills and knowledge. The aim of this study was to investigate how the use of the 3D virtual dissection table "Anatomage", like a platform for teaching of the students, transforms the tutor's roles. In years 2016-2019 ten tutors learned the virtual technology well enough to utilize it in the practical classes and to integrate new, modern content into Human Anatomy curriculum at Department of Morphology. Tutors used virtual dissection platform and tools for a variety of purposes and in many ways. New technology helped tutors to develop topics with more interactive, complex tasks and collaboration among students, promoted required assessment methods and student self-assessment. Based on the variety of roles played by the Human Anatomy tutor in this virtual experience, through the focus groups we were fixed four main tutor's roles types (technical, pedagogical, social and leadering). Variations in the usage of the "Anatomage" offered and reflected important performances, differences and divergences in tutors and their`s beliefs about the utility of this technology in the study course.
\end{abstract}

Keywords: anatomy, performances, roles, teaching, tutor, virtual technology.

\section{Introduction}

In any study or teaching-learning process a tutor (teacher) is present in the center (Taylor, Yates, Meyer, \& Kinsella, 2011). It is understandable, that nowadays or in this digital, technical period, the tutor plays not only a general, prior role and a link to the knowledge of students but forms developmental changes in different disciplines or study subjects (Ang, Chan, Gopal, \& Li Shia, 2018). The integration of the technologies in every area has changed this time education system in radical and different ways. According to this, a tutor has got new and additional responsibilities to keep balance with the performances, changes and influence of technologies on the teaching and learning environments. It is clear that the process of education is being changed through multiple ways of digital transformation in study subject Human Anatomy at Rīga Stradiṇš 
Kazoka \& Pilmane, 2020. Tutor`s Roles and Performances in Modern Human Anatomy Course Supported by Virtual Technology

University (RSU). New technologies and their possibilities through the introduction of virtual learning environments will have a profound effect on the interaction of the learner with the place of the education and with her or his learning which consequently transforms the role of the tutor (Trelease, 2016). According to this situation, it is clear that tutors will need to revise their roles as academic tutors.

We have seen that this time period invites us to think about another way of passing on knowledge. Tutors need to move away from some old methods and start to integrate the digital skills that students already have with the new ones they are acquiring. To study, learn and adapt to the digital tools, one principle is to give students an active role in their teaching. It is very important the building of the digital skills for the future. In Human Anatomy all our students deserve a quality education integrated with modern tools of the virtual technology or virtual dissection table "Anatomage" that is available to the tutors for the anatomy teaching to the students.

This article focuses on the tutors that teach the medical students throughout their learning process in study course Human Anatomy. The purpose of this study was to investigate how the use of the 3D virtual dissection table "Anatomage", like a platform for Human Anatomy teaching of the students, transforms the tutor's roles involved in a modern learning environment.

\section{Material and methods}

In years 2016-2019 tutors learned the virtual technology well enough to utilize it in the practical classes and to integrate new, modern content into Human Anatomy curriculum at Department of Morphology (RSU). For this study, 10 tutors were interviewed and this method was used for data collection. Selection of tutors was based on an open and voluntary invitation. Importantly, their topic areas related to all the major content offered in Human Anatomy program in different semesters. Students were trained to analyze anatomical structures via virtual dissection table "Anatomage" (Table Application software from Anatomage, Inc. (Table EDU 4.0 and Table EDU 6.0), USA) and views on different regions of the male and female bodies.

The interview questions were designed to find differences and/or similarities by comparing the answers of the tutors. Two structured questions were asked:

1) How does the use of the $3 \mathrm{D}$ virtual dissection table "Anatomage" impact tutor's roles and performances?

2) What are the roles and performances of tutors in modern Human Anatomy course supported by virtual technology?

The interview was conducted in a one-on-one interview. The questions were related to the four dimensions of the tutor roles, including technical support, issues 
of pedagogy and social interaction, and course leadering. Each interview took approximately 10 to 15 minutes. In the present study, four roles (technical, pedagogical, social and leadering) have been used as a framework to describe key roles and performances of the tutors.

\section{Results}

New technology helped tutors to develop topics with more interactive, complex tasks and collaboration among students, promoted required assessment methods and student self-assessment. Students expected all tutors to be well prepared and encouraging and treat them as individuals. Most of the tutors had a high level and content of the knowledge to teach Human Anatomy course at the Department of Morphology. 20\% tutors had an introduction to pedagogical knowledge in special educational courses. Although similar in many aspects tutors differed in a number of ways.

All of the tutors used virtual dissection platform and tools for a variety of purposes and in many ways, allowed learners to analyze, dissect, simulate procedures and/or visualize, manipulate information differently. Possibilities and digital tools of the virtual dissection table were used as an introduction for students to a topic, as part of practical classes or demonstrations, as providing access to regions of the body and dissection of them, digital activities and procedures, as a stimulation to every individual student or groups for discussion, as allowance students to work individually or in different groups, collaborator learning, access to different structures, parts, regions of the body, activities that are not possible in the practical class, orientation or review, extension activities of the students.

Variations of the tutors in this technology usage reflected important differences in tutors' beliefs about the utility of it in the study process. Perhaps the most common reason mentioned by tutors for not actively integrating new technologies was that $20 \%$ tutors were satisfied with their current lesson plans. Traditional tutors typically utilized their knowledge to transmit information by lecturing. Most tutors or $70 \%$ who participated in the study wished for special training where they could be trained on how to integrate virtual dissection technology into the practical classes. 50\% tutors helped other tutors by sharing instructional resources or implement effective teaching strategies and new ideas. When these tutors learned with and from one another, they focused on what most directly improves student teaching and learning.

There was a small number of tutors or $20 \%$ who were not adequately prepared or equipped to operate effectively in new virtual learning environment. $10 \%$ tutors reported having limited time to review and learn about new technology tools that they could use in their teaching. Their first activities in the teaching 
Kazoka \& Pilmane, 2020. Tutor`s Roles and Performances in Modern Human Anatomy Course Supported by Virtual Technology

were very stressful and demanding. Later these activities were better as they became familiar with virtual dissection table, content and digital tools.

Even though there were some challenges and performances, tutors liked their job. They were enthusiastic and willing to listen to their students and other tutors. The roles and performances found from the interviews were divided into four categories. A summary of some roles of the tutors is showed in Table 1.

The technical role

All our 10 tutors made students comfortable with the software program, system and tools of the virtual dissection table used for study course. This role decreased as students and tutors were more experienced users and as the digital tools were more frequent used.

Pedagogical role or intellectual role

In practical classes $80 \%$ tutors guided and maintained students' involment in discussions or debates, performed interesting and productive learning and teaching process of different anatomical topics. 20\% tutors focused on direct relevant content and issues of clinical cases that were included in virtual digital library.

Table 1 Some roles of the tutors in Human Anatomy study course

\begin{tabular}{|l|l|l|l|}
\hline \multicolumn{1}{|c|}{ Technical } & \multicolumn{1}{|c|}{ Social } & \multicolumn{1}{|c|}{$\begin{array}{c}\text { Pedagogical } \\
\text { (intellectual) }\end{array}$} & \multicolumn{1}{c|}{ Leadering } \\
\hline $\begin{array}{l}\text { preparing of the } \\
\text { virtual dissection } \\
\text { table }\end{array}$ & $\begin{array}{l}\text { support and creation } \\
\text { of friendly } \\
\text { environment }\end{array}$ & $\begin{array}{l}\text { performing interesting, } \\
\text { productive learning- } \\
\text { teaching }\end{array}$ & $\begin{array}{l}\text { organizational } \\
\text { practice }\end{array}$ \\
\hline $\begin{array}{l}\text { preparing of the } \\
\text { software program } \\
\text { and possibilities }\end{array}$ & $\begin{array}{l}\text { controlling of the } \\
\text { behavior in practical } \\
\text { class }\end{array}$ & teaching tolerance & $\begin{array}{l}\text { planning and } \\
\text { trying different } \\
\text { methods }\end{array}$ \\
\hline $\begin{array}{l}\text { preparing of the } \\
\text { digital tools }\end{array}$ & $\begin{array}{l}\text { working with staff } \\
\text { and colleagues }\end{array}$ & $\begin{array}{l}\text { development higher } \\
\text { order thinking }\end{array}$ & $\begin{array}{l}\text { exchange between } \\
\text { ideas }\end{array}$ \\
\hline $\begin{array}{l}\text { preparing of the } \\
\text { equipment }\end{array}$ & $\begin{array}{l}\text { preparing of the } \\
\text { practical class, } \\
\text { lecture }\end{array}$ & $\begin{array}{l}\text { assessment, self- } \\
\text { assessment and } \\
\text { evaluation }\end{array}$ & $\begin{array}{l}\text { development of } \\
\text { course and } \\
\text { curriculum }\end{array}$ \\
\hline technical guide & consistent behavior & $\begin{array}{l}\text { increasing of the } \\
\text { motivation }\end{array}$ & $\begin{array}{l}\text { guiding students, } \\
\text { cooperation }\end{array}$ \\
\hline technical support & $\begin{array}{l}\text { adoption to the } \\
\text { changes and self- } \\
\text { development }\end{array}$ & $\begin{array}{l}\text { pedagogical transitions, } \\
\text { innovations }\end{array}$ & $\begin{array}{l}\text { manager of the } \\
\text { practical class }\end{array}$ \\
\hline $\begin{array}{l}\text { planning of the } \\
\text { technical sources }\end{array}$ & opening to feedback & $\begin{array}{l}\text { pedagogical support and } \\
\text { help }\end{array}$ & $\begin{array}{l}\text { evaluation and } \\
\text { creativity }\end{array}$ \\
\hline
\end{tabular}


Social role

The social function was typically support and creation of comfortable, friendly social environment, collaborative learning and community, team feelings in which students showed that study process was possible. 100\% tutors developed harmony in their practical classes. But this study has showed that in some cases tutors (70\% beginners and 30\% seniors) had difficulties to use new social roles into teaching process.

Leadering role

The largest part or $80 \%$ tutors improved their skills, organizational and instructional practice as leaders in work with virtual dissection table. They shared their experience through peer coaching, exchanged ideas and helped develop a supportive environment. There were also mentioned evaluation, planning and trying different teaching methods as performances. 20\% tutors reported that dealing with students' special needs were challenges for them.

\section{Discussion}

Human Anatomy belongs to the morphological disciplines and comprises a large amount of material and structures. According to this, it serves as a bridge for knowledge between basic and clinical studies (Zilverschoon, Vincken, \& Bleys, 2017).

Traditionally the tutors use different materials (specimens, books, presentations, wall charts, etc.) and resources of the anatomy teaching process in the practical classes. Nowadays the teaching effect is updated with the help of a variety of digital platforms (Brucoli, Boccafoschi, Boffano, Broccardo, \& Benech, 2018), technologies (Oh, Kim, Chung, \& Choi, 2015), illustrations (McCarty, Gołofit, Tigges, \& Skalski, 2018), devices (Pyörälä et al., 2019) and virtual tools (Erolin, Reid, \& McDougall, 2019).

Teaching of anatomy in a modern medical course is changed with integration of innovative methodologies (Erolin, 2019). Tutors are faced with challenges, performances and barriers all the time. There is no doubt that new generation of the students is much more digital oriented than their previous generation (El Bialy \& Jalali, 2015). Today, with access to the internet and/or a simple click on a smartphone or smart device, every student can connect with anatomical information sources at almost anywhere and almost anytime (Attardi, Barbeau, \& Rogers, 2018).

In our new society, information and communication technologies have a profound impact on the way we learn (Peterson \& Mlynarczyk, 2016). At the same time, tutor must develop, improve the sustainable education and prepare the different generations of our society for better life, benefits or for better and more bright future. The ways of how tutors interact and/or work with students are 
Kazoka \& Pilmane, 2020. Tutor`s Roles and Performances in Modern Human Anatomy Course Supported by Virtual Technology

transformed in other options. The tutors working in higher education institutions have to understand difference between "learning about" and "learning to be". An effective tutor in the digital era has to know where to find relevant information, how to solve problems and what to keep up learning.

Today the prerequisites for a tutor are the inspiration and guiding the students in the use and expanding of the digital, virtual tools and skills (Wilson et al., 2018). There are several studies that showed that in the 21st century a tutor is or will be digital tutor (Juneja \& Juneja, 2017). The culture of higher education is moving away from teacher-centered learning towards learner-directed learning (Guimarães et al., 2017).

Several researchers point out that our modern learners needs tutors who can use the technologies available to them for quality teaching and learning (Singh \& Min, 2017). In Human Anatomy course the tutors must be prepared for the digital realities of the 21st century, learning needs of all our students (Arantes, Arantes, \& Ferreira, 2018).

To be adequately prepared for the practical classes, tutors must reach the 21st century knowledge and skills and be in the position to integrate them into their methods for learners to receive qualitative education and results in Human Anatomy course. The use of virtual dissection table impacts not only on the ways in which tutors teach but also on the ways in which learners learn. Mobile, virtual and digital devices are parts of the tutor's professional toolbox (Bernardo, 2017). Functions of the tutors are work as facilitators, coaches, consultants or resource people who provide intellectual guidance for student learning (Meedya, Moroney, Nielsen, \& Najafi Bokat, 2019). Different authors argue that the new digital roles of tutors may be more complicated than in traditional practical classes (Doubleday \& Lee, 2016). The roles may be intricately related with each other because one issue can cut across two or more areas (Sweet, 2017).

Exploration of the roles of the tutors in this study suggested that the interplay among practical class tutor roles is very complex. This study focused on one the following question: What were tutors' roles and their performances when teaching Human Anatomy with use of virtual dissection table? Virtual dissection table is undoubtedly a powerful tool, but the tutor must first learn the technology well enough to utilize it in a practical class setting before deciding how to integrate the technology with class objectives and curriculum. In our study was found that there was extensive variance among tutors about how they manage or realize their roles in this program.

There is need to think how tutors could be trained to ensure that all students acquire the skills they need to reach high level of knowledge, skills and results, otherwise teaching may leed to different inequalities (Wu et al., 2019). Tutor should be geared to prepare students to understand the relationship between content of the study subject and possibilities of the virtual dissection technology. 
Teachers need to not only have all virtual tools and the training to use them, they must also have the ability to inspire students to see their larger possibilities and potential (Stepan et al., 2017).

This study also indicated that several prominent factors affected roles of the tutors. To help anatomy tutors make a successful transition from traditional teaching to modern teaching, data from this study indicated a need for our Department not only to plan future roles, but also to provide substantial training support and best practices for implementing those roles.

As some authors (Pickering \& Roberts, 2018) point out, knowledge and skills of the tutors are important factors in the use of technology in the practical class but there are the situations that lack or limit of specific technological skills are a common reasons tutors give for not using technology (Helle, Nivala, \& Kronqvist, 2013).

Our experience showed that the way in which Human Anatomy has been teached has changed over the years. In future we will continue to develop our understanding, skills and practice regarding the use of technology to help our students learn effectively.

\section{Conclusions}

Medical tutors demonstrated their passion and had a possitive effect on students. There were several differences that were identified between tutors from the very start of use of virtual dissection table until advanced use of it.

Based on the variety of roles played by the Human Anatomy tutor in this virtual dissection experience, it was found that this study showed four main types of roles (technical, pedagogical, social and leadering). Some of the roles were assumed to function maximally, if they were equally expressed.

\section{Aknowledgements}

We would like to thank all the tutors for their time, experience and involvement in this study.

\section{References}

Ang, E.T., Chan, J.M., Gopal, V., \& Li Shia, N. (2018). Gamifying anatomy education. Clinical Anatomy, 31, 997-1005. DOI: 10.1002/ca.23249.

Arantes, M., Arantes, J., \& Ferreira, M.A. (2018). Tools and resources for neuroanatomy education: a systematic review. BMC Medical Education, 18, 94. DOI: 10.1186/s12909018-1210-6

Attardi, S.M., Barbeau, M.L., \& Rogers, K.A. (2018). Improving Online Interactions: Lessons from an Online Anatomy Course with a Laboratory for Undergraduate Students. 
Kazoka \& Pilmane, 2020. Tutor`s Roles and Performances in Modern Human Anatomy Course Supported by Virtual Technology

Anatomical Sciences Education, 11, 592-604. DOI:10.1002/ase.1776.

Bernardo, A. (2017). Virtual Reality and Simulation in Neurosurgical Training. World Neurosurgery, 106, 1015-1029. DOI: 10.1016/j.wneu.2017.06.140.

Brucoli, M., Boccafoschi, F., Boffano, P., Broccardo, E., \& Benech, A. (2018). The Anatomage Table and the placement of titanium mesh for the management of orbital floor fractures. Oral Surgery, Oral Medicine, Oral Pathology, Oral Radiology, 126, 317-321. DOI: https://doi.org/10.1016/j.oooo.2018.04.006

Doubleday, A.F., \& Lee, L.M. (2016). Dissecting the voice: Health professions students' perceptions of instructor age and gender in an online environment and the impact on evaluations for faculty. Anatomical Sciences Education, 9, 537-544. DOI: 10.1002/ase.1609

El Bialy, S., \& Jalali, A. (2015). Go Where the Students Are: A Comparison of the Use of Social Networking Sites Between Medical Students and Medical Educators. JMIR Medical Education, 1, e7. DOI: 10.2196/mededu.4908

Erolin, C. (2019). Interactive 3D Digital Models for Anatomy and Medical Education. Advances in Experimental Medicine and Biology, 1138, 1-16. DOI: https://doi.org/10.1007/978-3-030-14227-8_1

Erolin, C., Reid, L., \& McDougall, S. (2019). Using virtual reality to complement and enhance anatomy education. Journal of Visual Communication in Medicine, 42, 93-101. DOI: 10.1080/17453054.2019.1597626.

Guimarães, B., Dourado, L., Tsisar, S., Diniz, J.M., Madeira, M.D., \& Ferreira, M.A. (2017). Rethinking Anatomy: How to Overcome Challenges of Medical Education's Evolution. Acta Médica Portuguesa, 30, 134-140. DOI: 10.20344/amp.8404

Helle, L., Nivala, M., \& Kronqvist, P. (2013). More technology, better learning resources, better learning? Lessons from adopting virtual microscopy in undergraduate medical education. Anatomical Sciences Education, 6, 73-80. DOI:10.1002/ase.1302

Juneja, S., \& Juneja, M. (2017). Virtual digital pathology: The future is near. Indian Journal of Pathology and Microbiology, 60, 306-307. DOI: 10.4103/IJPM.IJPM_324_16

McCarty, J.L., Gołofit, P., Tigges, S., \& Skalski, M. (2018). Digital Medical Illustration for the Radiologist. Radiographics, 38, 1145-1157. DOI: 10.1148/rg.2018170088

Meedya, S., Moroney, T., Nielsen, W., \& Najafi Bokat, I. (2019). Digital explanations and nursing students' perception of learning science. Nurse Education in Practice, 41, 102636. DOI: https://doi.org/10.1016/j.nepr.2019.102636

Oh, C.S., Kim, K., Chung, E., \& Choi, H. (2015). Digital report in an anatomy laboratory: a new method for team-based dissection, reporting, and evaluation. Surgical and Radiologic Anatomy, 37, 293-298. DOI: https://doi.org/10.1007/s00276-014-1353-z

Peterson, D.C., \& Mlynarczyk, G. (2016). Analysis of traditional versus three-dimensional augmented curriculum on anatomical learning outcome measures. Anatomical Sciences Education, 9, 529-536. DOI: 10.1002/ase.1612

Pickering, J.D., \& Roberts, D.J.H. (2018). Flipped classroom or an active lecture? Clinical Anatomy, 31, 118-121. DOI: 10.1002/ca.22983.

Pyörälä, E., Mäenpää, S., Heinonen, L., Folger, D., Masalin, T., \& Hervonen, H. (2019). The art of note taking with mobile devices in medical education. BMC Medical Education, 19, 96. DOI: 10.1186/s12909-019-1529-7

Singh, A., \& Min, A.K. (2017). Digital lectures for learning gross anatomy: a study of their efficacy. Korean Journal of Medical Education, 29, 27-32. DOI: 10.3946/kjme.2017.50

Stepan, K., Zeiger, J., Hanchuk, S., Del Signore, A., Shrivastava, R., Govindaraj, S., \& Iloreta, A. (2017). Immersive virtual reality as a teaching tool for neuroanatomy. Internal Forum 
of Allergy and Rhinology, 7, 1006-1013. DOI: 10.1002/alr.21986

Sweet, R.M. (2017). The CREST Simulation Development Process: Training the Next Generation. Journal of Endourology, 31, S69-S75. DOI: 10.1089/end.2016.0613

Taylor, M., Yates, A., Meyer, L.H., \& Kinsella, P. (2011). Teacher professional leadership in support of teacher professional development. Teaching and Teacher Education, 27(1), 85-94. DOI: https://doi.org/10.1016/j.tate.2010.07.005

Trelease, R.B. (2016). From chalkboard, slides, and paper to e-learning: How computing technologies have transformed anatomical sciences education. Anatomical Sciences Education, 9, 583-602. DOI: https://doi.org/10.1002/ase.1620

Wilson, A.B., Miller, C.H., Klein, B.A., Taylor, M.A., Goodwin, M., Boyle, E.K., Brown, K., Hoppe, C., \& Lazarus, M. (2018). A meta-analysis of anatomy laboratory pedagogies. Clinical Anatomy, 31, 122-133. DOI: https://doi.org/10.1002/ca.22934

Wu, Y., Hikspoors, J.P.J.M., Mommen, G., Dabhoiwala, N.F., Hu, X., Tan, L.W., Zhang, S.X., \& Lamers, W. H. (2019). Interactive three-dimensional teaching models of the female and male pelvic floor. Clinical Anatomy, Oct, 1-11. DOI: https://doi.org/10.1002/ca.23508

Zilverschoon, M., Vincken, K.L., \& Bleys, R.L. (2017). The virtual dissecting room: Creating highly detailed anatomy models for educational purposes. Journal of Biomedical Informatics, 65, 58-75. DOI: https://doi.org/10.1016/j.jbi.2016.11.005 